\title{
Usefulness of intraoperative touch smear cytology in breast-conserving surgery
}

\author{
KAZUHIRO SUMIYOSHI ${ }^{1}$, TAKEHIRO NOHARA ${ }^{1}$, MITSUHIKO IWAMOTO $^{1}$, SATORU TANAKA $^{1}$, \\ KOSEI KIMURA ${ }^{1}$, YUKO TAKAHASHI ${ }^{1}$, YOSHITAKA KURISU ${ }^{2}$, MOTOMU TSUJI $^{2}$ and NOBUHIKO TANIGAWA ${ }^{1}$ \\ Departments of ${ }^{1}$ General and Breast and Endocrine Surgery, and ${ }^{2}$ Pathology, Osaka Medical College, Osaka 569-8686, Japan
}

Received March 16, 2010; Accepted Mayz 17, 2010

DOI: 10.3892/etm_00000100

\begin{abstract}
In breast-conserving surgery, positive margins are closely related to intramammary recurrence, but methods of assessing resection stumps during breast-conserving surgery have not been standardized. The present study investigated the usefulness of intraoperative touch smear cytology in our department. From 2005 to 2008, a total of 420 patients underwent breast cancer surgery. Subjects comprised 160 patients who underwent breast-conserving surgery and touch smear cytology. Results of the touch smear cytology were compared to those of the histological tissue analysis. Touch smear cytology displayed $70 \%$ sensitivity (14/20), $97.1 \%$ specificity (136/140) and a diagnostic accuracy of 93.8\% (150/160). Six false-negative cases and 4 false-positive cases were identified. Of the 6 false-negatives, cancer cells were noted in the ductal component in 5 cases, and the degree of cancer cell atypia in the stump was low. Residual cancer cells were noted in the stump in 18 cases, and additional resection was performed in 16 cases. Cancer cells were identified histologically in the additionally resected tissue in 8 of these 16 cases $(50 \%)$. The direction of positive cytology was towards the nipple in 16 cases, lateral tissue in 5 cases and contralateral nipple in 2 cases. A greater cancer cell volume, as assessed by touch smear cytology, tended to be associated with higher frequency of positive margins, as assessed by histological tissue analysis. Touch smear cytology is easy to perform, offering a very useful technique yielding comparable results to histological tissue analysis.
\end{abstract}

\section{Introduction}

The desire for breast-conserving surgery in patients being treated for early breast cancer has modified the management of these patients. With the recent widespread use of breast-

Correspondence to: Dr Nobuhiko Tanigawa, Department of General and Breast and Endocrine Surgery, Osaka Medical College, 2-7 Daigaku-machi, Takatsuki, Osaka 569-8686, Japan

E-mail:sur001@poh.osaka-med.ac.jp

Key words: touch smear cytology, breast cancer, breast-conserving surgery conserving surgery, assessing the extent of tumor spread has become increasingly important (1-4). In breast-conserving surgery, positive margins are closely related to intramammary recurrence (5-8), but methods of assessing resection stumps during breast-conserving surgery have not been standardized. The present study investigated the usefulness and pitfalls of intraoperative touch smear cytology (touch cytology) in our department.

\section{Patients and methods}

From 2005 to 2008, a total of 420 patients underwent breast cancer surgery. Subjects comprised 160 patients (1 man, 159 women; mean age 58.1 years; range 22-82 years) who underwent breast-conserving surgery and touch smear cytology. Patient and tumor characteristics are listed in Table I. Mean tumor histological size was $24.8 \mathrm{~mm}$. Tumors included 7 non-invasive ductal carcinomas (4.4\%), 79 papillotubular carcinomas (49.4\%), 12 solid-tubular carcinomas (7.5\%), 35 scirrhous carcinomas $(21.9 \%)$ and 27 special types $(16.9 \%)$. Moreover, the degree of atypia was mild [nuclear grade (ng)1] in 70 cases (43.8\%), moderate (ng2) in 50 cases $(31.3 \%$ ) and severe (ng3) in 40 cases (25\%).

The method of touch cytology involved touching the resected stump to the slide glass, then performing fixation as promptly as possible using $95 \%$ ethanol with a prepared box. Specimens were examined for the presence of cancer cells using Papanicolaou stain. Additional resection was performed during the operation, in principle, when the surgical cut end was positive. A permanent tissue section was constructed, and the total segmentation was cut at intervals of $5 \mathrm{~mm}$. Results of touch smear cytology were compared to those of the histological tissue analysis. Cancer nests were defined as exposure in either direction regardless of invasion or intraductal component with positive margins in a permanent tissue section.

\section{Results}

Touch cytology displayed $70 \%$ sensitivity (14/20), $97.1 \%$ specificity (136/140) and a diagnostic accuracy of $93.8 \%$ (150/160). Six false-negative cases and 4 false-positive cases were identified (Table II). Residual cancer cells were noted in touch cytology in 18 of the 160 cases (Table III). The direction of positive cytology was towards the nipple in 16 cases 
Table I. Patient and tumor characteristics.

\begin{tabular}{lc}
\hline Gender & \\
Female & 159 \\
Male & 1 \\
Age (years) & $22-82$ \\
Range & 58.1 \\
Median & $24.8 \pm 7$ \\
Tumor size (mm) & \\
Histological type, no. of cases (\%) & $7(4.4)$ \\
Non-invasive ductal ca (1a) & $79(49.4)$ \\
Papillotubular ca (2a1) & $12(7.5)$ \\
Solid-tubular ca $(2 \mathrm{a} 2)$ & $35(21.9)$ \\
Scirrhous ca (2a3) & $27(16.9)$ \\
Special type & \\
Nuclear grade, no. of cases $(\%)$ & $70(43.8)$ \\
Grade 1 & $50(31.3)$ \\
Grade 2 & $40(25.0)$ \\
Grade 3 & \\
\hline
\end{tabular}

Table II. Diagnostic accuracy of touch cytology.

\begin{tabular}{|c|c|c|c|}
\hline \multirow[t]{2}{*}{ Resection stumps } & \multicolumn{2}{|c|}{ Touch cytology } & \multirow[t]{2}{*}{ Total $(\%)$} \\
\hline & Positive (\%) & Negative $(\%)$ & \\
\hline \multicolumn{4}{|c|}{ Tissue section (permanent) } \\
\hline Positive & $14(8.8)$ & $6 \quad(3.8)$ & $20 \quad(12.5)$ \\
\hline Negative & $4(2.5)$ & $136(85.0)$ & $140 \quad(87.5)$ \\
\hline Total & $18(11.3)$ & $142(88.8)$ & $160(100.0)$ \\
\hline
\end{tabular}

$(88.9 \%)$, the lateral tissue in 5 cases $(27.8 \%)$ and the contralateral nipple in 2 cases (11.1\%) (Fig. 1). Residual cancer cells were noted in the stump in 18 cases, and additional resection was performed on 16 cases, excluding 2 cases with few cells showing low-level atypia.

In 4 of the 18 cases with touch cytology margin-positive results (cases 3, 6, 12 and 17), cancer cells were not observed in the resection stump before additional resection in permanent tissue sections (false-positive cases). Assessing cancer cells was very difficult, since very few cancer cells were apparent. Cases 10 and 12 were mucinous carcinomas, and the mucin outflow when stamping the specimen appeared to have caused the false-positive results. The possibility of similar falsepositives must be considered even with intracystic tumors.

Cancer cells were identified histologically from 8 of the 16 cases $(50 \%)$ with additionally resected tissue. In one typical case, intraoperative additional resection was performed (Table III, case 9). Breast-conserving surgery was performed (right breast, internal lower area). Intraoperative touch cytology towards the nipple and lateral tissue sides was cut-end positive. Cancer cells were observed both in the additional resection tissue and resection stump before additional resection was performed in the permanent tissue section. Greater cancer cell
1 direction: 13 cases

2 directions: 5 cases

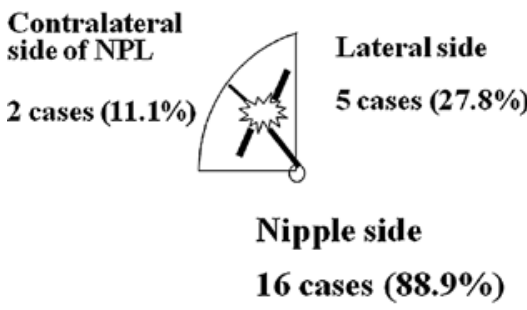

Figure 1. Direction of positive touch cytology (total 18 cases: 1 direction, $\mathrm{n}=13 ; 2$ directions, $\mathrm{n}=5$ ). Direction of positive cytology was predominantly towards the nipple side.

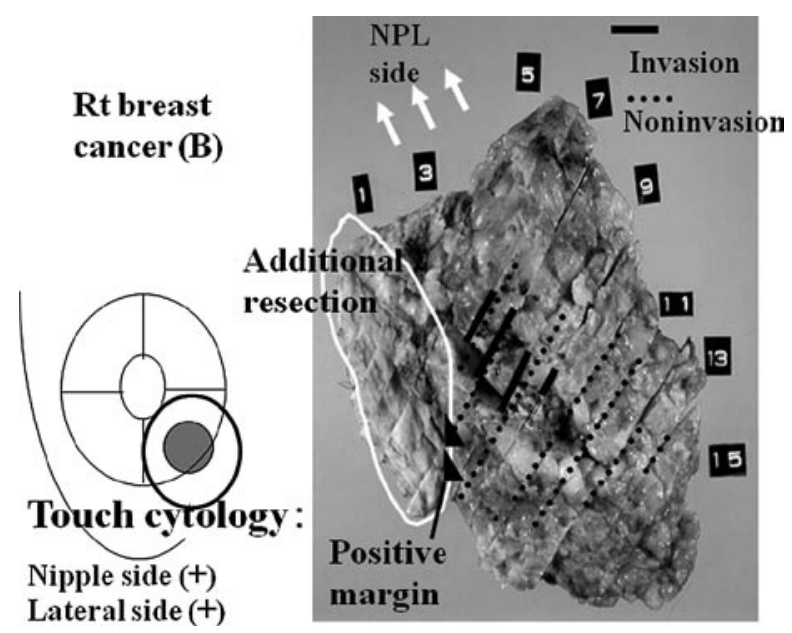

Figure 2. Example (case 9). Breast-conserving surgery was performed (right breast cancer, internal lower area). Intraoperative touch cytology towards the nipple side and lateral tissue side was cut end-positive. Cancer cells were noted in both the additional resection tissue and resection stump before performing additional resection in the permanent tissue section.

volume, as assessed by touch smear cytology, tended to be associated with a higher frequency of positive margins, as assessed by histological tissue analysis (cases 2 and 5). Additional resection was performed twice in each of these cases. A touch cytology specimen from case 2 is shown in Fig. 3. Numerous cancer cells showed dyshesion among cells and severe atypia in the background of necrotic cells, and a positive margin was diagnosed. Given the presence of a positive margin, additional resection was again performed. In addition, the ng 3 case was not included among the 18 cases with touch cytology-positive margins, suggesting that the diagnosis of cancer by touch cytology may be possible even when a low degree of nuclear atypia is identified.

On the other hand, 6 cases showed positive margins in permanent tissue sections, despite no appearance of cancer cells on touch cytology (false-negative cases). False-negative cases are shown in Table IV.

Of the 6 false-negative cases, cancer cells were noted in the ductal component in 5 cases, and the degree of cancer cell atypia in the stump was low. Moreover, no cases with positive margins showed lymphatic invasion. 
Table III. Positive touch cytology cases $(n=18)$.

\begin{tabular}{|c|c|c|c|c|c|c|c|c|}
\hline \multirow[b]{2}{*}{ Case } & \multirow[b]{2}{*}{$\begin{array}{c}\text { Age } \\
\text { (years) }\end{array}$} & \multirow[b]{2}{*}{$\begin{array}{l}\text { Histological } \\
\text { type }\end{array}$} & \multirow[b]{2}{*}{$\begin{array}{l}\text { Nuclear } \\
\text { grade }\end{array}$} & \multirow[b]{2}{*}{$\begin{array}{l}\text { Tumor size } \\
\text { (mm) }\end{array}$} & \multirow{2}{*}{$\begin{array}{c}\text { Direction of } \\
\text { positive } \\
\text { touch cytology }\end{array}$} & \multirow[b]{2}{*}{$\begin{array}{l}\text { Intraoperative } \\
\text { treatment }\end{array}$} & \multicolumn{2}{|c|}{$\begin{array}{c}\text { Permanent histological } \\
\text { analysis (cancer cell + or -) }\end{array}$} \\
\hline & & & & & & & $\begin{array}{l}\text { (Before additional } \\
\text { resection) Stump }\end{array}$ & $\begin{array}{l}\text { Additional } \\
\text { resected tissue }\end{array}$ \\
\hline 1 & 67 & $2 \mathrm{a} 3$ & 2 & 26 & NPL & Additional resection & + & - \\
\hline 2 & 56 & $2 \mathrm{a} 1$ & 2 & 18 & NPL $(++)$ & $\begin{array}{l}\text { i) Additional resection } \\
\text { ii) Additional resection }\end{array}$ & + & i) + ii) + \\
\hline 3 & 47 & $2 \mathrm{a} 1$ & 2 & 11 & NPL & Additional resection & - & - \\
\hline 4 & 41 & $2 \mathrm{a}(\operatorname{mix})$ & 1 & 32 & NPL & Additional resection & + & + \\
\hline 5 & 37 & $2 \mathrm{a} 1$ & 2 & 0 & $\operatorname{NPL}(++)$ & $\begin{array}{l}\text { i) Additional resection } \\
\text { ii) Additional resection } \\
\text { (on another day) }\end{array}$ & + & i) + ii) + \\
\hline 6 & 51 & $2 \mathrm{a} 1$ & 2 & 42 & Lat & Additional resection & - & - \\
\hline 7 & 51 & $2 \mathrm{a} 1$ & 1 & 20 & NPL, Lat & Additional resection & + & - \\
\hline 8 & 41 & $2 \mathrm{a} 1$ & 2 & 15 & NPL & Additional resection & + & - \\
\hline 9 & 42 & $2 \mathrm{a} 3$ & 1 & 40 & NPL, Lat & Additional resection & + & + \\
\hline 10 & 35 & $2 \mathrm{~b} 1$ & 1 & 23 & NPL, Lat & Additional resection & $+($ lateral side $)$ & - \\
\hline 11 & 81 & $2 \mathrm{a} 1$ & 1 & 30 & $\begin{array}{c}\text { NPL, } \\
\text { Contralateral }\end{array}$ & Additional resection & + & - \\
\hline 12 & 38 & $2 \mathrm{~b} 1$ & 1 & 19 & NPL & Additional resection & - & - \\
\hline 13 & 58 & $2 \mathrm{a} 1$ & 1 & 16 & NPL & Additional resection & + & + \\
\hline 14 & 48 & $2 \mathrm{a} 3$ & 1 & 12 & NPL, Lat & Additional resection & + & + \\
\hline 15 & 71 & $2 \mathrm{a} 1$ & 1 & 13 & Contralateral & None & + & \\
\hline 16 & 66 & $1 \mathrm{a}$ & 2 & 0 & NPL & Additional resection & + & + \\
\hline 17 & 59 & $2 \mathrm{a} 3$ & 2 & 18 & NPL & None & - & \\
\hline 18 & 56 & $2 \mathrm{a} 3$ & 2 & 22 & NPL & Additional resection & + & + \\
\hline
\end{tabular}

1a, non-invasive ductal carcinoma; 2a, invasive carcinoma; 2a1, papillotubular carcinoma; 2a3, scirrhous carcinoma; 2b1, mucinous carcinoma. ++ , Numerous cancer cells.

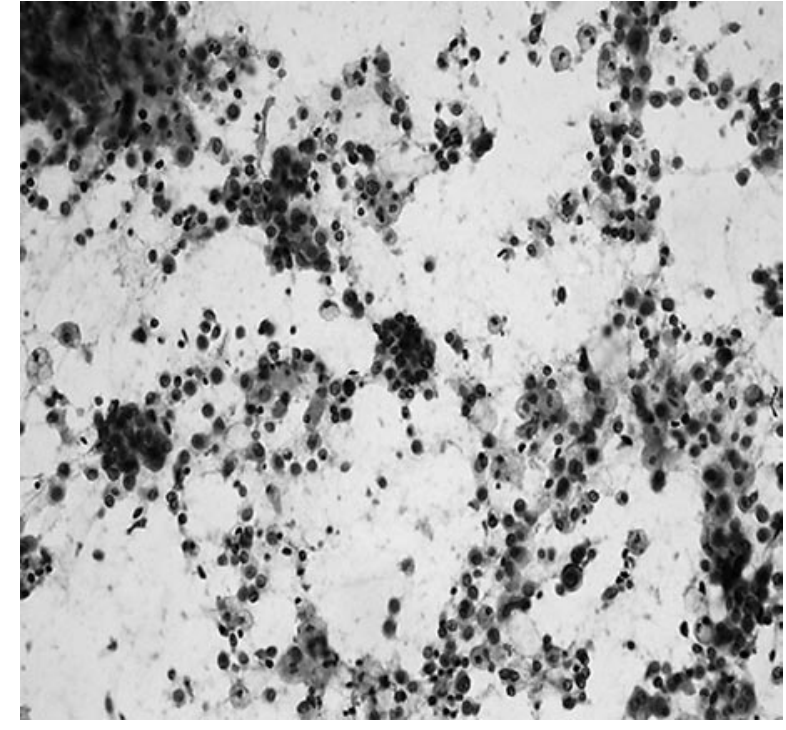

Figure 3. Touch cytology specimen (case 2) (Papanicolaou stain, x200). Numerous cancer cells are noted in the touch cytology specimen towards the nipple.

\section{Discussion}

We previously reported that the direction of the intraductal component was towards the nipple in $48.7 \%$, lateral in $40.8 \%$ and towards the contralateral nipple in $28.9 \%$ (including overlapping cases) of the cases (9). Importantly, care must be taken to investigate, not only the nipple side, but also the lateral and contralateral nipple sides. In the present study, the direction of positive touch cytology was towards the nipple in 16 cases $(88.9 \%)$, lateral in 5 cases $(27.8 \%)$ and towards the contralateral nipple in 2 cases (11.1\%) (Fig. 1). As the intraductal component towards the nipple side covered a long distance, margins were considered to easily become positive in many cases.

Histological tissue analysis and touch smear cytology can be performed to assess resection stumps during breastconserving surgery. Histological tissue analysis is accurate, but i) analyzing all areas of a large resection stump is difficult; ii) preparing high-quality frozen sections is difficult due to the high adipose content of breast tissue; iii) assessing the 
Table IV. False-negative cases $(\mathrm{n}=6)$.

\begin{tabular}{|c|c|c|c|c|c|c|}
\hline Case & $\begin{array}{c}\text { Age } \\
\text { (years) }\end{array}$ & $\begin{array}{l}\text { Histological } \\
\text { type }\end{array}$ & $\begin{array}{l}\text { Nuclear } \\
\text { grade }\end{array}$ & $\begin{array}{l}\text { Tumor size } \\
\qquad(\mathrm{mm})\end{array}$ & $\begin{array}{l}\text { Direction of positive margin, } \\
\text { invasion or intraductal (no.) }\end{array}$ & $\begin{array}{l}\text { Additional } \\
\text { therapy }\end{array}$ \\
\hline 1 & 63 & $2 \mathrm{a} 1$ & 3 & 18 & $\begin{array}{l}\text { Contralateral side of NPL: } \\
\text { invasion ( } 1 \text { piece) }\end{array}$ & Radiation \\
\hline 2 & 39 & $2 \mathrm{a} 1$ & 1 & 26 & NPL side: intraductal (1 piece) & Radiation \\
\hline 3 & 51 & $2 \mathrm{a} 1$ & 3 & 11 & NPL side: intraductal (2 pieces) & Radiation \\
\hline 4 & 42 & $2 \mathrm{a} 3$ & 3 & 20 & $\begin{array}{l}\text { Lateral side: intraductal ( } 2 \text { pieces }) \\
\text { Contralateral side of NPL: intraductal ( } 1 \text { piece) }\end{array}$ & Radiation \\
\hline 5 & 62 & $1 \mathrm{a}$ & 1 & 0 & $\begin{array}{l}\text { NPL side: intraductal (1 piece) } \\
\text { Lateral side: intraductal ( } 1 \text { piece) }\end{array}$ & Radiation \\
\hline 6 & 60 & $2 \mathrm{a} 1$ & 3 & 17 & $\begin{array}{l}\text { NPL side: intraductal ( } 1 \text { piece) } \\
\text { Lateral side: intraductal ( } 3 \text { pieces })\end{array}$ & $\begin{array}{l}\text { Additional resection } \\
\quad+\text { radiation }\end{array}$ \\
\hline
\end{tabular}

Touch cytology, negative; permanent histological analysis, positive. 1a, non-invasive ductal carcinoma; 2a1, papillotubular carcinoma; 2a3, scirrhous carcinoma.

Table V. Comparison of the accuracy of histology and cytology for assessing intraoperative resection stumps.

\begin{tabular}{|c|c|c|c|c|c|c|c|c|}
\hline & \multirow[b]{2}{*}{$\mathrm{n}$} & \multirow[b]{2}{*}{$\begin{array}{l}\text { No. of } \\
\text { Stumps }\end{array}$} & \multicolumn{3}{|c|}{ Histological analysis } & \multicolumn{3}{|c|}{ Touch cytology } \\
\hline & & & $\begin{array}{c}\text { Sensitivity } \\
(\%)\end{array}$ & $\begin{array}{c}\text { Specificity } \\
(\%)\end{array}$ & $\begin{array}{c}\text { Accuracy } \\
(\%)\end{array}$ & $\begin{array}{c}\text { Sensitivity } \\
(\%)\end{array}$ & $\begin{array}{c}\text { Specificity } \\
(\%)\end{array}$ & $\begin{array}{c}\text { Accuracy } \\
(\%)\end{array}$ \\
\hline Cox et al (10) & 114 & & 77.3 & 100 & 95.5 & 100 & 96.6 & 97.3 \\
\hline Morita et al (11) & 205 & 241 & 68.3 & 56.0 & 85.5 & & & \\
\hline Morita et al (11) & 58 & 66 & & & & 77.0 & 66.7 & 87.9 \\
\hline Nagumo et al (16) & 68 & 138 & 64.3 & 100 & 92.8 & 78.6 & 92.7 & 89.9 \\
\hline Miyauchi et al (12) & 114 & & & & & 87.2 & 86.6 & 86.8 \\
\hline Kato et al (13) & 33 & 132 & & & & 100 & 90.7 & 92.4 \\
\hline Tohnosu et al (14) & 50 & 200 & & & & 96.4 & 90.7 & 91.5 \\
\hline Creager et al (15) & 137 & 758 & & & & 75.0 & 95.5 & 94.5 \\
\hline
\end{tabular}

malignancy of intraductal proliferating lesions is difficult; and iv) regions of the tissue sample may be damaged. Touch smear cytology is easily performed, offering a very useful technique yielding comparable results to histological tissue analysis. In contrast, touch smear cytology has some disadvantages. i) Assessment is difficult in cases from which too few cells are obtained; ii) assessing lesions showing low-grade atypia is difficult; and iii) a special cytology screener and physician are essential.

In many reports the result of cut end assessment using touch cytology is identical to that of frozen tissue section, and touch cytology offers the key advantage of providing an easy technique (10-16).

Cut end assessment using frozen tissue sections offers $77.3 \%$ sensitivity, $100 \%$ specificity and $95.5 \%$ accuracy according to Cox et al (10); $68.3 \%$ sensitivity, $56 \%$ specificity and $85.5 \%$ accuracy as reported by Morita et al (11); while $64.3 \%$ sensitivity, $100 \%$ specificity and $92.8 \%$ accuracy were reported by Nagumo et al (16). In the present study, the results of cut end assessment using touch cytology showed 70-100\% sensitivity, 66.7-97.1\% specificity and 86.8-97.3\% accuracy (Table V). Results for touch cytology were equally accurate or more accurate than for frozen tissue sections.

Misdiagnosed lesions by touch cytology assessment were reported to include i) papillary lesions, ii) lesions showing low-grade atypia, iii) lesions showing few cells and iv) lesions with ductal hyperplasia or ductal carcinoma in situ $(12,13)$.

In our examination, touch cytology assessment showed 97.1\% specificity and $93.8 \%$ accuracy, representing excellent results compared to other reports, although sensitivity was slightly low at $70 \%$. Causes of false-negative cases $(n=6$; Table IV) that contributed to the lower sensitivity included the 
following. i) Sampling error: investigation in only 1-2 directions may detect relatively few cancer cells. ii) Staining: in cases using touch cytology specimens stained by Papanicolaou stain after fixing in $95 \%$ ethanol, sensitivity is slightly low and specificity is high (17). That is, cells flake off easily in cases with fixation in ethanol. However, dry fixations, such as other Diff-Quick methods and Giemsa staining, are unsuitable for detailed observation of heavy cell populations and are a ready cause of misdiagnosis. iii) Underestimation: in case 5 (Table IV) intraoperative touch cytology assessment was cut end-negative since the few cells present showed monotonous nuclei with little atypia.

The examination of cut ends requires the use of information from touch cytology (cellularity and cell atypia) and considering likely histological types, but without strict intraoperative judgment of the cut end.

Some key points must be considered in touch cytology examination (16). First, after removing blood with gauze, the resection stumps must be touched slightly onto the slide glass (when stumps are touched too firmly, intraductal lesions may be pushed out, causing false-positive results). Second, cytology specimens must be fixed in $95 \%$ ethanol immediately, without allowing time for drying. Third, degenerative cells must not be misdiagnosed. Fourth, when touch cytology diagnosis (i.e., benign vs. malignant) is difficult to assess, a comparison to a pre-operative aspiration cytology specimen is useful. Finally, a cytologist must collaborate on the diagnosis with a surgeon.

In our hospital, in all cases irradiation to the remaining breast is performed in principle after breast-conserving surgery. Ipsilateral breast recurrence was not identified in any of the cases (160 samples), although surveillance was only continued for a relatively short period. Takahashi et al reported that when cancer cells include only an intraductal component or are noted in only one direction or in only one specimen, the recurrence rate is low in the ipsilateral breast without postoperative irradiation (17). Only 1 case with 4 slices showing cut end-positive results on permanent tissue section required additional resection at a later date among the 6 false-negative cases. Strict follow-up is required.

Cut ends are often difficult to assess even in permanent tissue sections since extreme intraductal component atypia is low. Detailed cut end evaluation with a permanent tissue section appears to allow accurate and efficient diagnosis after initial intraoperative touch cytology to provide prompt, easy and accurate diagnosis.

\section{References}

1. Fisher B, Redmond C, Poisson R, et al: Eight-year results of a randomized clinical trials comparing total mastectomy and lumpectomy with and without radiation on the treatment of breast cancer. N Engl J Med 320: 822-828, 1989.

2. Polednak AP: Trends in breast-conserving surgery in Connecticut: no effect of negative publicity. Conn Med 60: 527-530, 1996.

3. Kotwall CA, Covington DL, Rutledge R, et al: Patient, hospital, and surgeon factors associated with breast conservation surgery: a statewide analysis in North Carolina. Ann Surg 224: 419-429, 1996.

4. Voogd AC, Nab HW, Crommelin MA, et al: Comparison of breast-conserving therapy with mastectomy for the treatment of early breast cancer in community hospitals. Eur J Surg Oncol 22: 13-16, 1996.

5. Park CC, Mitsumori M, Nixon A, et al: Outcome at 8 years after breast-conserving surgery and radiation therapy for invasive breast cancer: influence of margin status and systemic therapy on local recurrence. J Clin Oncol 18: 1668-1675, 2000.

6. Anscher MS, Jones P, Prosnitz LR, et al: Local failure and margin status in early-stage carcinoma treated with conservation surgery and radiation therapy. Ann Surg 218: 22-28, 1993.

7. Kurtz JM, Jacquemier J, Amalric R, et al: Why are local recurrences after breast-conserving therapy more frequent in younger patients? J Clin Oncol 8: 591-598, 1990.

8. Nixon AJ, Schnitt SJ, Gelman R, et al: Relationship of tumor grade to other pathologic features and to treatment outcome of patients with early stage breast carcinoma treated with breastconserving therapy. Cancer 78: 1426-1431, 1996.

9. Sumiyoshi K, Kani H, Nohara T, et al: A comparison study between multidetector-row CT and histopathological findings in terms of the extension diagnosis of breast cancer. J Jpn Surg Assoc 67: 1463-1472, 2006.

10. Cox CE, Ku NN, Reintgen DS, Greenberg HM, Nicosia SV and Wangensteen S: Touch preparation cytology of breast lumpectomy margins with histologic correlation. Arch Surg 126: 490-493, 1991.

11. Morita T, Shin E, Takatsuka Y, et al: Significance of intraoperative pathologic consultation in breast-conserving surgery. Jap $\mathrm{J}$ Breast Cancer 12: 673-678, 1997.

12. Miyauchi M, Yamamoto N, Fujita Y, et al: Clinical significance of rapid imprint cytology to ensure the cancer free margin in breast conservative surgery. Jpn J Breast Cancer 9: 1293-1297, 1994.

13. Kato T, Takahashi $\mathrm{H}$, Ando $\mathrm{T}$, et al: Intraoperative rapid imprint cytologic examination of surgical margin in breast cancer conserving surgery. J Jpn Soc Clin Cytol 36: 119-123, 1997.

14. Tohnosu N, Nabeya Y, Matsuda M, et al: Rapid intraoperative scrape cytology assessment of surgical margins in breast conservation surgery. Breast Cancer 5: 165-169, 1998.

15. Creager AJ, Shaw JA, Young PR and Geisinger KR: Intraoperative evaluation of lumpectomy margins by imprint cytology with histologic correlation: a community hospital experience. Arch Pathol Lab Med 126: 846-848, 2002.

16. Nagumo $\mathrm{S}$, Motomura $\mathrm{K}$, Kasugai $\mathrm{T}$, Inaji $\mathrm{H}$ and Koyama $\mathrm{H}$ : Intraoperative cytological examination: diagnosis of surgical margins and sentinel nodes in breast cancer. Jpn J Breast Cancer 18: 16-23, 2003.

17. Takahashi K, Akiyama F, Yamashita T and Sakamoto G: Role of radiation therapy in breast conserving therapy in relation to the surgical margin status. Jpn J Breast Cancer 21: 435-441, 2006. 